\title{
A Geometric Greek Horse in the Nicholson Museum
}

Although its origins are unknown, this small bronze statuette ${ }^{1}$ could well have come from Olympia, judging by its patina and by eight very similar figurines found in this sanctuary. ${ }^{2}$ These animals, which are distinguished by an exaggeratedly large head, and by the very noticeable contrast between the substantial body and the feet, which are considerably wider than they are thick, are typical products of the craftsmen of Olympia. ${ }^{3}$

From the 9th century B.C. these craftsmen produced the greatest number of votive animals within Greece. The sudden influx of both pilgrims visiting the shrine and visitors during the competitions is sufficient to explain the production of many thousands of votive animals, mostly cattle and horses. The pilgrims and other visitors offered to the divinities the figure of the animal which they considered the most important. Their choice was made from a social rather than an economic point of view. The relationship between the horse and the aristocracy or between the bull and the peasantry is particularly obvious. This kind of votive offering decreased rapidly and went out of fashion soon after the end of the Geometric Period, circa 700 B.C., from which time the donors preferred to dedicate weapons and ex-votos, often displaying oriental influence.

Of course, the bronzesmiths of the North-West Peloponnese were not the only ones to work in Olympia, ${ }^{4}$ but their work has a distinctive style, concentrating on expressing the vitality of the animals. ${ }^{5}$ The open mouth, the prominent and irregular eyes, the widespread ears and even the fore hooves which barely touch the ground, are all characteristics which clearly associate the Sydney horse with Olympia. The unstable posture and the accentuation of expressive detail add to the vitality of

${ }^{1}$ Inv. no. 64.324. Green patina, with some dark patches and superficial damage. The edges of the hooves are jagged, and there is some residual metal on the inside of the hooves and under the belly. H. $62 \mathrm{~mm}$; L. $90 \mathrm{~mm}$. Sold at Christie's, April 28, 1964, Cat. of Antiquities (London 1964), no. 56, pl. 6.2; A. Cambitoglou, Nicholson Museum, Classical Collection (Sydney 1979), case 4, panel 2. Presented by the Friends of the Nicholson Museum. I am grateful to Professor Alexander Cambitoglou for allowing me to publish this statuette. Translation by Thérèse Ramseyer.

2 The provenance of this statuette could be confirmed by analysing the alloy, because, in the present state of research, the votive animals of Olympia are the only bronzes of the Geometric period which contain gold; cf. W.-D. Heilmeyer, Olympische Forschungen (OF) 12 (Berlin 1979), 283. The small but constant amount of gold could be explained by the need of an anti-oxidant to stabilise the bronze.

${ }^{3}$ Ibid. 139-158, 170-179 and especially 137 .

${ }^{4}$ Cf. W.-D. Heilmeyer, JdI 84 (1969), 1 ff.

${ }^{5}$ This gives the animals of Olympia an unintentionally caricatured and almost grotesque appearance, being modelled in soft wax before the casting, with exaggerated facial features: OF 12 (1979), nos. 824-917. 
this elongated statuette. The apparent contradiction of the expressive head and the more simply fashioned body can be explained by the two major traditions which inspired the bronze-smiths of Olympia: the terracotta modelling tradition ${ }^{6}$ and the metallurgical tradition inherited from the local blacksmiths. ${ }^{7}$

To judge from its posture, the distance between the feet and the shape of the hooves, the Sydney horse was an independent offering, designed without a stand, and not part of the handle of a tripod, the most precious ex-voto in early Greek sanctuaries. Considering the horse within its own Olympian context, it is particularly interesting for two reasons. First, it is one of those rare local statuettes which show a real stylistic originality and where the quality is superior to that of the majority of figurines made at Olympia, which were mass-produced ${ }^{8}$ in response to a periodic demand during religious ceremonies, other festivities and of course the Olympic games. Secondly, the Sydney horse shows sufficient resemblance to a small group of animals associated with Olympia to attribute them to one hand, and more precisely to the colleague of an artist of whose work we have identified two statuettes, ${ }^{9}$ and who worked during the last quarter of the 8th century B.C.

It is obviously difficult to attribute several bronzes to one artist, because each lost-wax casting creates a unique object. ${ }^{10}$ However, it is possible to identify the work of particular individuals, ${ }^{11}$ taking into account not only the stylistic similarities, but also various indications which point to the same method of manufacture. These indications show mainly how the wax was worked, ${ }^{12}$ and the problems with casting $^{13}$ and finishing the bronze statuettes. ${ }^{14}$ The creator of the

${ }^{6} \mathrm{~A}$ craftsman certainly modelled the wax of the horse from Olympia Br. 2265 (OF 12 [1979], no. 319, cf. terracotta, OF 7 [1972], no. 97, pl. 17), before giving it to a bronzesmith for casting by the lost-wax process. Such a collaboration is common at Olympia, contra Heilmeyer, $O F 12$ (1979), 53.

${ }^{7}$ Numerous thread-like statuettes testify to this: $O F 12$ (1979), nos. 668-672 and 680685 . Note also the improvement of faults remaining after casting with hammer and tongs; cf. Heilmeyer, OF 12 (1979), 49, 144, 178.

${ }^{8} \mathrm{Cf}$. H.-V. Herrmann, Bonner Jb. 182 (1982), 613-619. A horse and bull cast at the same time: $O F 12$ (1979), no. 31.

${ }^{9}$ a) Paris, coll. F. Stafford, a standard group of a mare and her foal: D.G. Mitten-S.F. Doeringer, Master Bronzes from the Classical World (Mainz 1968), 36, fig. 15; Heilmeyer, OF 12 (1979), 106 n.144; F. Hiller, JdI 94 (1979), 28 n.25.

b) Formerly on the Zürich market, $\mathrm{H}$. Vollmoeller, Cat. Schweiz. Kunst- $u$. Antiquitätenmesse (Basel 1976), 33.

${ }^{10}$ That is why the attribution of bronzes is more difficult than that of figured pottery; cf. J.N. Coldstream in R. Hägg, Greek Renaissance of the Eighth Century B.C. (Stockholm 1983), 17, 23.

${ }^{11}$ Cf. D.G. Mitten, BMFA 67 (Boston 1965), 14 n.26; H. Hoffmann, Ten Centuries that Shaped the West (Houston 1971), 148, under no. 69.

12 Modelling of particular details and ridges covered by the flashes.

${ }^{13}$ For the Sydney horse, oblong casting residues along the hooves (cf. here no. 4) and irregularities on the belly (cf. $O F 12$ [1979], no. 726).

${ }^{14}$ For the group described here: chiselling of the horses' manes (nos. 2-3); hammering of the horses' tails (no. 6 and $O F 12$ [1979], no. 726). 
Sydney horse demonstrates the same style and the same method of manufacture in the following twelve statuettes:

1. Sydney, Nicholson Museum 64.324: horse. Plate 1 (Photo R.K. Harding, Nicholson Museum).

2. Berlin Charlottenburg Mus. 01.10127 (K. Neugebauer, Bronzen I [Berlin 1931] no. 104): horse, from Olympia.

3. Olympia Mus. B. 2106 (W.-D. Heilmeyer, OF 12 [1979], no. 725): horse.

4. Olympia Mus. K 883 (ibid. no. 727): horse. Plate 2, left (German Archaeological Institute, Athens, Neg.Nr. 69/442).

5. Olympia Mus. O.Nr. (ibid. no. 728): horse. Plate 2, right (German Archaeological Institute, Athens, Neg.Nr. 69/442).

6. Sotheby's (London, May 20th, 1985, no. 286, pl. 28): horse, probably from Olympia (Neg. German Archaeological Institute, Athens, Olympia 326, no. 8).

7. Olympia Mus. B.1347 (Heilmeyer, OF 12 [1979], no. 771): bull. Plate 4 (German Archaeological Institute, Athens, Neg.Nr. 01.1468).

8. Olympia Mus. K 837 (ibid. no. 772): bull. Plate 5 (German Archaeological Institute, Athens, Neg.Nr. 69/441).

9. Olympia Mus. B 2398 (ibid. no. 773): bull. Plate 3 (German Archaeological Institute, Athens, Neg.Nr. 01.7221).

10. Berlin, private coll. (K. Vierneisel, Antiken aus Berliner Privatbesitz [1976], no. 29): bull.

11. Sotheby-Parke-Bernet, sale (New York, November 20th-21 st, 1975, no. 629): bull.

12. Swiss private coll.: bull. Plate 6: this statuette could be either a work of the same craftsman, or possibly an animal produced by his workshop (Photo D. Widmer, Basel).

The wax reproduction of the details of the head, and the position of the casting-seams and runners ${ }^{15}$ link these six stallions and six bulls. None of them has any kind of stand.

From the stylistic point of view, the artist is less influenced by the Laconian type than his colleague, the creator of the Paris and Zürich statuettes. ${ }^{16}$ The Sydney horse and related animals are more angular, and their surface detail more sharply defined. The artist has a highly personal way of exaggerating the long cylindrical head and of outlining the hooves. There is a subtle distinction between the fore and hind hooves, and they fulfil two separate functions: the hind hooves provide stability, while the fore hooves enhance the impression of mobility by hardly touching the ground. The long stiff tail at an angle, the shape of the neck and shoulders, the sharp division between head and neck and

${ }^{15}$ Probably divided, and placed above the statuette, on the rump and along the mane (cf. here no. 4).

${ }^{16} \mathrm{Cf}$. supra note 9 . The Laconian influence is most evident in the rectangular stand, decorated with pierced triangles and with a square piece to support the tail; cf. W.-D. Heilmeyer, OF 12 (1979), 122-123, figs. 8-9. 
the angular junction of the narrow shoulders, are characteristics common to all these bronzes.

Above all, these animals demonstrate the same way of expressing vitality by a particular interpretation of shape, and by the rhythm between the long curves and the shorter straight sections of the profile.

Although their artistic style differs slightly, the two artists mentioned above certainly formed part of the same studio. On comparison with other Peloponnesian artefacts from Olympia, ${ }^{17}$ their statuettes probably date from the last third of the 8th century B.C. ${ }^{18}$ The predominantly horizontal proportions and the asymmetry of both sides are characteristic of the style adopted during this period; the increasing size and growing roundness of the body mass also point to a late date of manufacture. ${ }^{19}$

The craftsman who created the Sydney horse and related animals is one of the rare bronzesmiths at Olympia to have been susceptible to influences other than Peloponnesian. He is obviously inspired by the Attic horses which decorated the handles of hammered tripods. ${ }^{20}$ Not only were many of these tripods available in Olympia in the second half of the 8th century, but some of them were so large that they probably had to be assembled 'in situ'. While the influence of the Attic style on Geometric Peloponnesian bronzes is admittedly only minor and late, it shows how varied the sources of inspiration were in Olympia, a shrine which attracted visitors from all over Greece from the end of the Geometric period on, and an important centre for the manufacture of bronzes, as is shown by the quantities of casting-waste found in the area. $^{21}$

University of Geneva

JEAN-LOUIS ZIMMERMANN

${ }^{17} \mathrm{Cf}$. ibid. nos. 361 and 566.

18 Ibid. 152, 155; contra H. Walter and K. Vierneisel, $A M 74$ (1959), 17.

${ }^{19} \mathrm{Cf}$. Heilmeyer, OF 12 (1979), nos. 336 and 730 . The horse 6211 of the National Museum at Athens could be another work of the artist of the Sydney horse, or more probably the work of a collaborator. This statuette seems slightly later than the others, because of its very effective expression of the lively and unbound quality of the galloping stallion. The rounded modelling is also significant.

20 In particular, the very characteristic shape of the neck and shoulders; cf. Olympia Mus. B 2041 (M. Maass, OF 10 [1978], no. 207) and the horses from the Acropolis, Athens MN 6539 and 6544 (A. de Ridder, Bronzes de l'Acropole [1896], nos 490491; M. Weber, $A M 89$ [1974], 27-30). The Attic influence is particularly noticeable on the horse Athens MN 6211: the shape of the mane and back, cf. MN 6543 (de Ridder no. 485); the surface treatment and expression of movement, cf. MN 6552 (de Ridder no. 493); shoulders and thighs, cf. MN 6545 (de Ridder no. 486). Hammered tripods, cf. M. Weber, $A M 86$ (1971), 20-29; E. Touloupa, $A M 87$ (1972), 57-72; C. Rolley, Etudes Déliennes 1 (1973), 504-506 and Fouilles de Delphes $5^{3}$ (1977), 7175,100 n.9; M. Maass, $O F 10$ (1978), 63-104.

${ }^{21} \mathrm{Cf}$. supra note 4. 


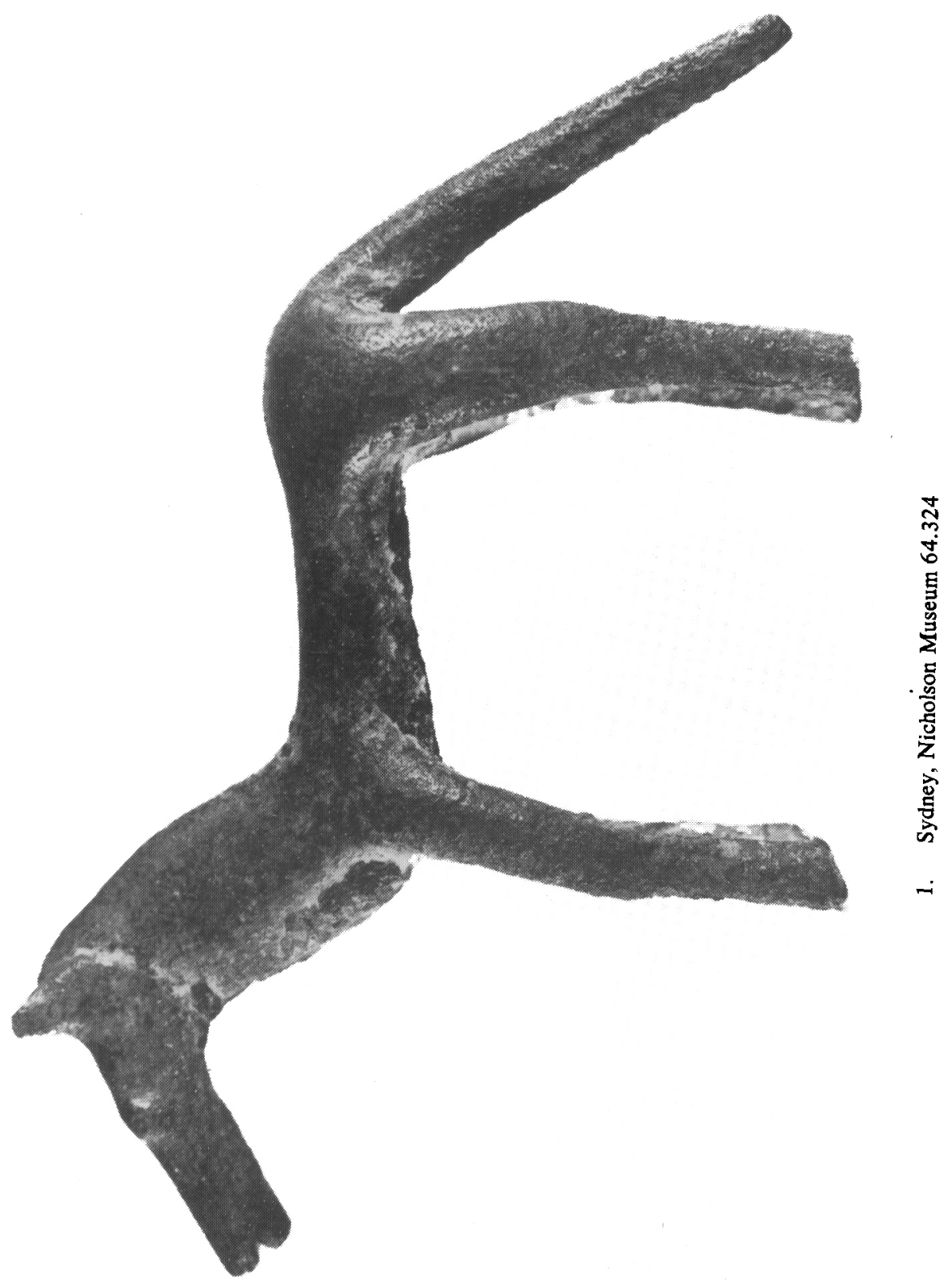




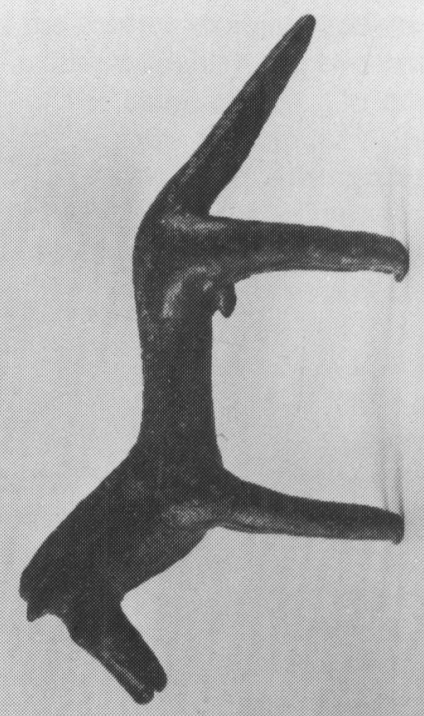

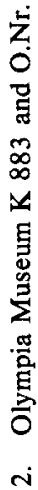




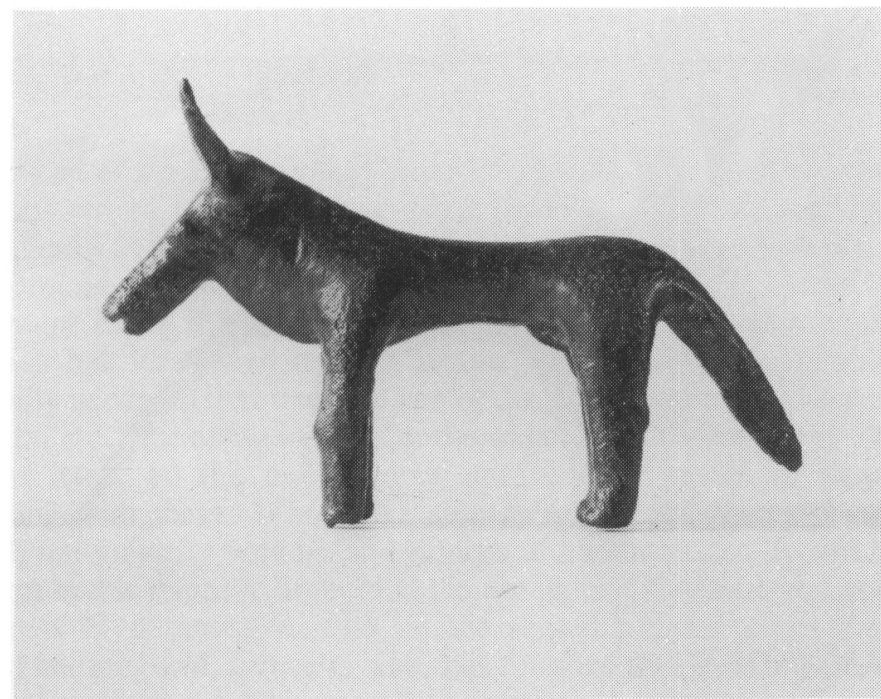

3. Olympia Museum B 2398

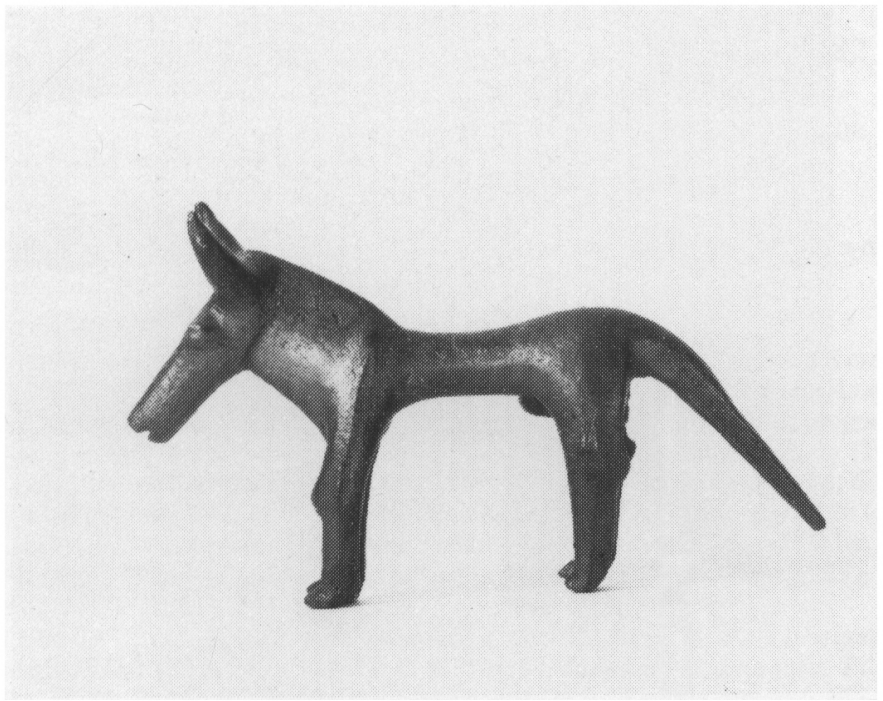

4. Olympia Museum B 1347 


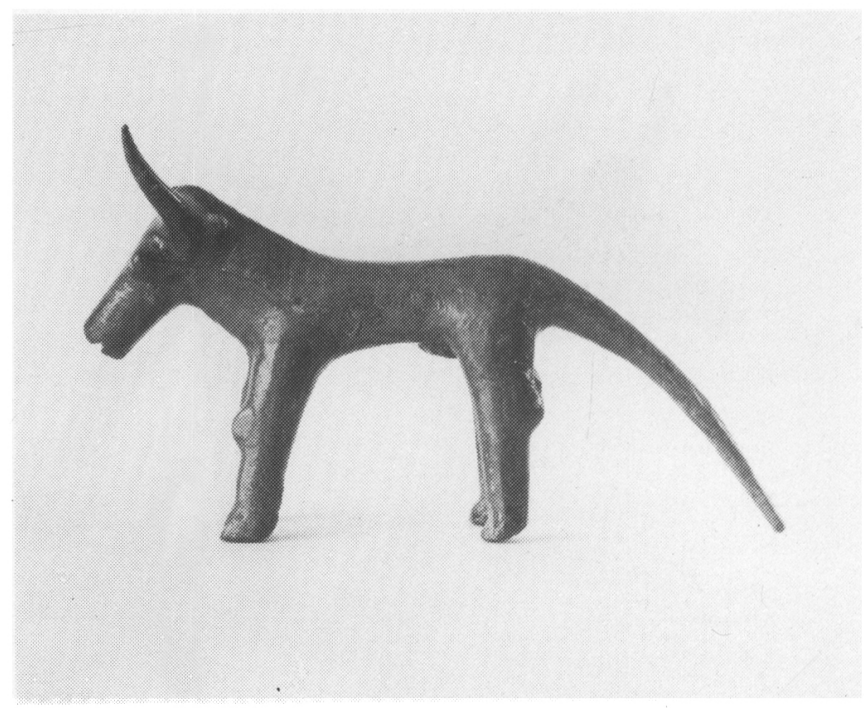

5. Olympia Museum K 837

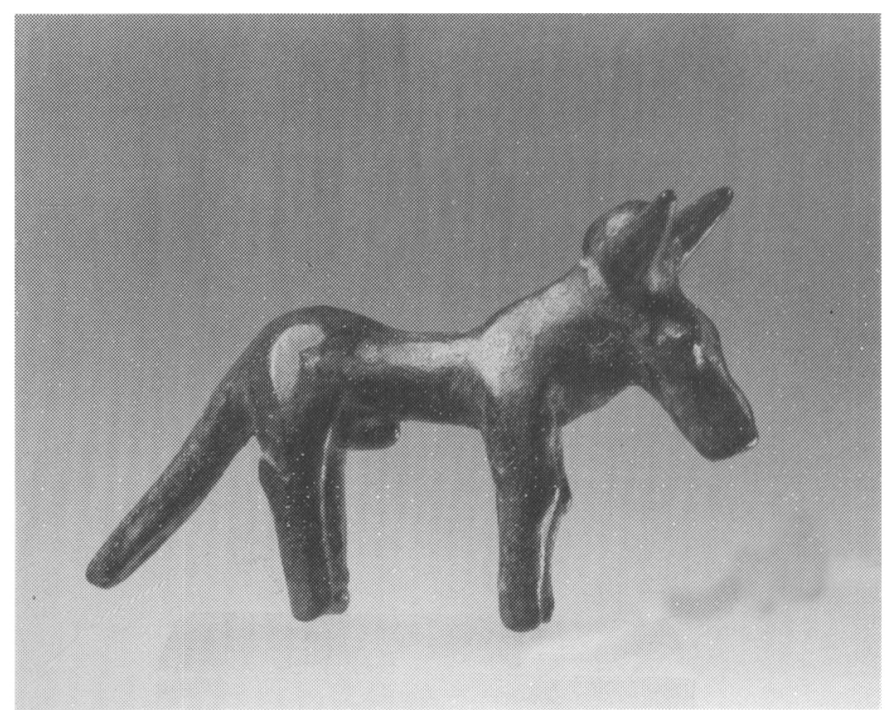

6. Swiss Private Collection 